\title{
Collective action problems: Disentangling possible feedback loops between government policies and the public's value-change
}

\author{
Eivind Hoff-Elimari, Common Cause Network, Norway \\ Anat Bardi, Royal Holloway University of London, United Kingdom \\ Simon Matti, Luleå University of Technology, Sweden \\ Kristina Östman, KTH Royal Institute of Technology, Sweden
}

\begin{abstract}
Solving collective action problems, such as poverty reduction or climate change, depends on interactions between governments' and voters' preferences regarding pro-social actions. This paper examines whether the overall direction of change in pro-social public policy precedes public value-change, rather than the other way around. We examine change in the public's pro-social values in six European countries, as measured by the European Social Survey (ESS) during 2002-2012. In these countries, we conducted an expert survey to rate governmental policy that expresses these values over the same period, thereby examining value-change in governmental policy. The chronological comparison of value-change of the public with that of respective governments suggests that changes in pro-social government policies may drive public value-change rather than vice versa. This complements previous studies focused on the opinion-policy connection. Possible political implications are discussed. The promising findings of this initial study point to the importance of conducting larger-scale future studies.
\end{abstract}

\section{JEL classification}

Z18.

\section{Keywords}

Values; policy feedback; democracy.

\section{Acknowledgements}

We would like to thank WWF-UK, in particular Tom Crompton, for the financial support and advice that enabled this research. We are also grateful to Ela Polek of University College Dublin for valuable advice and encouragement. Last but not least, we thank the anonymous political scientists who filled in the survey on governments' political goals. 


\section{Introduction}

This research addresses the feedback loop between national political agendas and value-priorities of the mass public in an attempt to further our understanding of how political space for addressing large-scale collective action problems evolves. Characterised by a temporal and spatial mismatch between costs and benefits, as well as between problem causes and problem effects, a range of large-scale collective action problems (e.g. Duit, 2011; Ostrom, 2000; Hodge \& McNally, 2000) or bigger-than-self problems (Crompton, 2010) exist as consistent challenges for modern societies. For example, deficits of public pension regimes reward the present beneficiaries at the expense of future tax-payers, and the impact of $\mathrm{CO} 2$ emissions today will be felt fully through climate change only in a few decades. Addressing these problems present a significant challenge for contemporary democratic governments. They cannot be addressed by appeals to individual (or national) self-interest alone but rather require an appeal to, and an activation of, the public's moral-normative concerns to trigger both public policy support and subsequent large-scale cooperative behaviour.

The interaction between public policy and public opinion has been a long standing interest within social science research. As a key characteristic of democracy (e.g., Dahl, 1989), an abundance of previous research has focused on the effects of opinion on policy, conceptualised as democratic responsiveness. Although the magnitude and stability of these effects are still unknown, most scholars agree that policy-makers, particularly with regard to high-salience issues, do not allow policy decisions to flow too far away from public preferences (Page \& Shapiro, 1983; Stimson, MacKuen \& Erikson, 1995; Glynn et al., 1999; Burstein, 2003; Wallner, 2008). However, when policy matches the opinions of the mass public, is this match a sign of a responsive policy or of a responsive public? Addressing the latter, researchers have demonstrated how political decision-makers regularly attempt to impact public opinion by emphasising certain values (Feldman, 1988; Caprara, Schwartz, Capanna, Vecchione \& Barbaranelli, 2006); framing their messages (Gilbert \& Lindzey, 1998; Rein \& Schön, 1993); and making "emotive appeals" believed to increase legitimacy (Wallner, 2008) when presenting policy proposals. Hence, although changes in mass-opinions give rise to new policy suggestions by responsive decision-makers, public opinion may also be affected by previous policy decisions. Indeed, an emerging literature on this interaction argues that the public policy - public opinion interaction, rather than focusing on a single direction of causality, should be thought of as a two-way system of feedback loops, comprising both a dynamic policy representation and a dynamic public responsiveness (e.g. the thermostatic model of responsiveness, cf. Wlezien, 1995, 1996, 2004; Soroka \& Wlezien, 2004, 2010).

Drawing on Easton's (e.g. 1953) traditional model of the political system, in which public reactions to policy outcomes constitutes new inputs to the system, these feedback loops can be both positive (self-reinforcing policy change) or negative (leading to policy reversal) (Skocpol, 1993; Soss \& Schram, 2007; Soroka \& Wlezien, 2010). For example, Pierson (1993) categorised these feedback effects between public policies and the mass public as resource and incentive effects and interpretive effects. The former have to do with the direct material impacts of public policies, which may create vocal constituencies that will defend existing policies or trigger opposition from those who lose out as a result of the policies. This is akin to research on retrospective voting (e.g., Fiorina, 1981) suggesting that past performances is a significant factor for evaluating political alternatives and candidate support in upcoming elections. The interpretive effects, on the other hand, change the public's own cognitive processes. Soss (1999) has demonstrated how one type of interpretive effect is political learning through individuals' direct experience with government programmes. Svallfors (2010) added that public policies may also trigger a normative feedback mechanism, which may be 
independent of direct experience of public policies. Seen this way, public policy may impact on publicly established views on how the world ought to be and thereby contribute to creating or expanding political space for addressing also the moral-normative issues and long time-horizons inherent in large-scale collective action problems. In short, new policy may indeed be conducive to new politics (e.g., Schattschneider, 1935). However, although the notion of a causal effect from policy to opinion has received increased attention during the past decades, research has primarily focused on how specific policies give rise to specific changes in opinion on the particular issue addressed in policy (Soss \& Schram, 2007; Soroka \& Wlezien, 2010). In most of the empirical literature, therefore, the broader political effects of policy - opinion interactions have been largely overlooked.

Recognising the link between large-scale collective action problems and human values and value change as documented by e.g. Schwartz (2006) or Schultz et al. (2005), the primary aim of this article is to explore whether the value-priorities expressed through national policy are associated with subsequent changes in the value-priorities of the mass public, in the case of large-scale collective-action problems. Thereby, this article contributes to further exploring one of the empirical links between public policy and public opinion: public responsiveness. To fulfil this aim, we use a combination of ESS data and expert surveys to compare how national policy goals and mass public values have changed in six European countries during 2002-2012. We do not seek to explain differences in the absolute levels of value priorities across countries but focus on changes in value scores.

In the next section, we further theorise the proposed feedback mechanism between national political agendas and mass public values, and outline a framework for mapping and comparing the two on the same canvas. The following section describes our method, survey and measurement strategies. The final two sections present our results and discuss their implications.

\section{Policy feedback and values}

If there are strong correlations between public policies and voters' preferences, how can the directions of effects between the two be established? It is tempting to consider policy and opinion as changing through "mutual adjustment, subject to a never-ending endogenous feedback loop" (Svallfors, 2010, p. 121). Although this may be true in many cases, in particular when viewed in a long-term perspective, it does not help much in understanding the drivers of changes to public policy and mass public opinion. This requires that each mechanism is studied independently. Therefore, in this paper, we explore the suggestion that changes in the value priorities reflected through governmental policy are associated with later changes in the public's value-priorities, implying that governments might have the ability to consciously influence the values of the public.

What is the basis to expect that value emphases of national policy would be associated with subsequent changes in the value-priorities of the mass public? As mentioned above, recent developments in political science research on responsiveness have demonstrated how the public indeed reacts to changes in policy. Although these reactions, in part, can be due to the real life effects of a policy (e.g. Pierson, 1993), public reactions to policy can also be a factor of the political information surrounding implementation processes, allowing the public to form opinions even without being familiar with the specifics of a policy change (Jacobs \& Shapiro, 2000; MacKuen, Erikson \& Stimson, 1992; Zaller, 1992). According to, for example, the thermostatic model of responsiveness (Wlezien 1995 \& 1996; Soroka \& Wlezien 2010), the public continuously gauge the difference between their preferred level and direction of policy and the reality of political decision-making, resulting both in short-term demands for policy 
adjustments as well as in long-term preference-modification in reaction to policy change.

The most prominent psychological process of value change to date is the process of adaptation (see detail and review in Bardi \& Goodwin, 2011). That is, personal values adapt to life circumstances such that for most values, those values that can be readily pursued and fulfilled become stronger, and those values whose pursuit is blocked become less important. This mechanism has been used in the past to explain the value profiles of citizens of former communist countries in Europe as an adaptation to life under communism (Schwartz \& Bardi, 1997). Furthermore, examining sub-populations, the value profiles of Polish migrants to the United Kingdom have become more similar to the values of United Kingdom residents the longer these migrants have remained in the country, probably as part of a process of adaptation (Bardi, Buchanan, Goodwin, Slabu, \& Robinson, 2014). A similar process of adaptation may lead values of the public to change and adapt to the values that governments pursue in their policies. Hence, it is plausible that values, as expressed implicitly in governments' policies, actions, and discourse, would later become more important in the public as part of adaptation to the current regime.

In order to explore and compare policy feedback loops, the primary task is to translate public policies and public opinion into something comparable across countries and over time. Basic human values offer such an object as both mass opinion and governmental policy can be conceptualised as expressing a coherent set of value-priorities. Public policy, defined broadly as the output of the political system (e.g. Dror, 1973; Premfors, 1989; Cochran \& Malone, 1995; Easton, 1953; Hjern, 1987), is to its essence constructed by a system of values specifying its ultimate goals and guiding the choice of strategies for reaching them (cf. Amara, 1972; Jenkins-Smith \& Sabatier, 1993; Kingdon, 1995). Values are thereby to be considered the "backstop" (Tetlock et al., 1996) of public policy, and the way in which value-conflicts and value trade-offs are handled throughout the political system thereby determining its content (Stewart, 2009; Thatcher \& Rein, 2004). Similarly, we know from both social psychology and public opinion research that people's opinions constitute a function of their general values (cf. Rokeach, 1973; Converse, 1964; Glynn et al., 1999) and that value-priorities serve as a shortcut for the formation of preferences on a range of political issues (e.g. Zaller, 1992; Jacoby, 2006; Altemeyer, 1998; Rasinski, 1987; Brewer \& Gross, 2005; Feldman, 1988; Hurwitz \& Peffley, 1987).

Schwartz (e.g., 2011) has shown that both individuals and cultures on all continents share a common structure of values, understood as guiding principles in life, arranging a set of ten motivational value-types. The proposed structure of individuals' values has been examined in 75 nations worldwide (Schwartz, 2011) and is widely referred to as a theoretical starting point in research on a number of socio-political issues (e.g., Davidov, Schmidt \& Schwartz, 2008; Caprara et al., 2006; Barnea \& Schwartz, 1998; Rohan \& Zanna, 1998 \& 1996; Sagiv \& Schwartz, 1995; Stern et al., 1995). According to Schwartz (1992), basic human values are organised in ten value types whose reciprocal relations can be represented as a circumplex (see Figure 1), where proximity on the circumference indicates that values are mutually compatible and that strengthening a value will strengthen neighbouring values, whereas diametrical opposition indicates the opposite: strengthening a value on one side of the circle will weaken the value on the opposite side.

This representation of basic values as a circle allows the identification of four higher-order value types according to two oppositions: Openness to change versus Conservation $(\mathrm{OtC} / \mathrm{C})$, focusing the conflict between willingness for change and the motivation to keep things as they are, and Self-enhancement versus Selftranscendence (SE/ST), focusing the conflict between prioritising selfish interests and prioritising the interests of others or one's group (Schwartz, 1992, p. 43). 
Figure 1: Schwartz value types

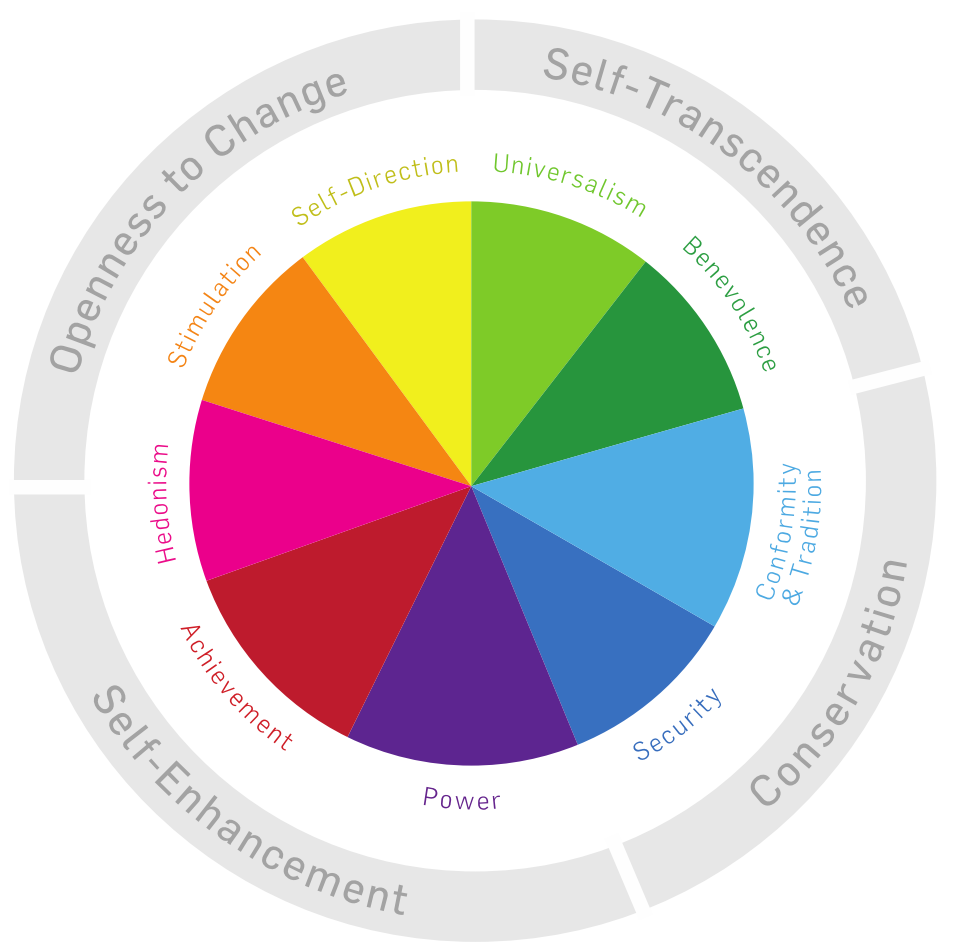

Source: Holmes, Blackmore, Hawkins \& Wakeford (2011)

Priorities amongst the basic values vary from individual to individual, from society to society and over time. The aggregate value priorities across societies form the very heart of culture (e.g., Hofstede, 1980; Schwartz, 1994) and are correlated with the public's political preferences (e.g., Caprara et al., 2006). For instance, selftranscendence values such as equality and unity with nature are closely related to pro-social and cooperating behaviour (e.g. Schwartz, 2006; De Groot \& Steg, 2008; Stern \& Dietz, 1994) as well as to environmental concern (Schultz et al., 2005). Similarly, the values that prevail in society are used by political leaders to set policies. For example, welfare laws are likely to prevail in countries where values of self-transcendence, such as justice and equality, are emphasised (Bardi \& Sagiv, 2003).

Although the OtC/C-dimension has been suggested as closely associated with general political-ideological reasoning, thereby predicting the formation of support for political parties and programmes primarily on matters concerning the stateindividual relationship, e.g. between conservatism and liberalism (cf. Schwartz, 1992; Barnea \& Schwartz, 1998; Caprara et al., 2006), the focus of this article is on how values of the SE/ST-dimension are materialised in public policy and through public opinion. As this paper focuses on policies addressing large-scale collective action or bigger-than-self problems, which require for their amendment that people prioritise the good of others rather than personal utility maximisation, the ST/SE focus on priorities concerning individual or collective benefits is the appropriate choice. In the next section we shall therefore examine empirically how six European countries moved in different directions on the SE/ST-dimension in the early 2000s and how their governments' corresponding policy goals evolved over the same time period. 


\section{Method and data}

\section{Method}

\section{Value-priorities expressed through public opinion}

The longest time series for regular measurements of Schwartz values at national level is the European Social Survey (ESS). It is conducted every second year since 2002 (2003 for some countries) across Europe (including Russia, Turkey and Israel). Each national survey consists of representative samples of between 1200 and 2800 respondents. A core module of questions has been included in all rounds. This module includes Schwartz' shortened 21-item Portrait Values Questionnaire (PVQ) to map values. The questions describe a characteristic of a fictitious person and the respondent is asked to evaluate how much the described person resembles him or her on a scale from 1 (very much like me) to 6 (not like me at all). Each of the ten value-types is expressed by two or three items. For example, one of the items for universalism is: "She/he strongly believes that people should care for nature. Looking after the environment is important to her/him."

For each respondent, a mean score of all PVQ items was first computed and subtracted from 7 to reverse the scale in order to make its interpretation more intuitive: A high score means a respondent generally felt much like the person portrayed. For each of the value types, power, achievement, benevolence and universalism, each respondent's mean score across the two or three items of the value type was calculated and the scale again reversed by subtracting it from 7 . The respondent's overall mean score across all the PVQ items was subtracted from each of these values and 5 were added to the figures for each respondent to eliminate any negative values. Each respondent's mean of power and achievement represent her self-enhancement score and the mean of universalism and benevolence represent her self-transcendence score.

We applied the demographic weights provided by ESS to compensate for overand under-representation of certain age groups and household types to calculate national mean self-transcendence and self-enhancement scores. The difference between the two is the compound indicator we used to compare public opinion over time. We refer to this as the public opinion net self-transcendence score.

\section{Value-priorities expressed through governmental policy}

The first five rounds of ESS gives a time series from 2002-2003 to 2010-2012 of changing value priorities of public opinion on the SE/ST-dimension. To study feedback effects, we also need a mirror measure of changes to governments' value priorities over the same time period. One option would have been to study changes to material effects of public policies of most obvious relevance to value priorities on the self-transcendence vs. self-enhancement opposition, such as marginal income tax, immigration or environmental policies. However, we found that official statistics were deficient in many fields before 2004 for newer EU Member States (e.g., on immigration or environmental policies) and/or they covered a very small part of what basic values might impact on (such as in the case of marginal income tax). Furthermore, there may be significant time lags - the material effects of public policies may appear long after they have been debated and adopted. We did searches of the frequency of keywords associated with the SE/ST-dimension on websites of heads of government over time (using Google Advanced Search) in order to infer governments' value priorities, but we found that results were extremely sensitive to the choice of single words and that it was not suited to compare governments. We decided instead to construct a compound indicator of what we could infer as being the different governments' value priorities on the SE/ST-dimension, based on experts' observations. 
As noted by Svallfors (2010), the normative feedback mechanisms of public policies that we are concerned with may be independent of direct experience of public policies: It matters not only what governments do (and don't), but also how they motivate their decisions. In other words, what matters is the sum of what the public perceives of government action and inaction. Due to the lack of consistent opinion polls on these matters, we decided to approach academic political scientists, whom we presumed would have followed national politics with interest since the first ESS round in 2002 whilst having relatively non-partisan views. We constructed a questionnaire (Political Scientists Survey - PSS) with 12 political goals representing typical government priorities that would be relevant across Europe over the last decade. This questionnaire was sent to political scientists in the six countries with the most significant variations in the public opinion net selftranscendence score in the period from 2002-2003 to 2010-2012. We used our networks to identify active researchers (with at least a $\mathrm{PhD}$ ) at universities with a good reputation in political science. Respondents were asked to rate the extent to which their countries' governments from 2002 to 2011 (we defined a government as the tenure of a head of government) prioritised each of the 12 goals (six reflecting SE-values, six reflecting ST-values) using a 5-point scale. The complete list and details of the methodology can be found in the Appendix. Mean scores for each of the 12 items for each government were calculated and then combined into a government net self-transcendence score for each government, defined as:

$(S T-S E)_{\text {government }}=\frac{\text { univer salism }_{2,8,10,12}+\text { benevolence }_{5,7}}{6}-\frac{\text { achievement }_{1,3,6,9}+\text { power }_{4,11}}{6}$

Finally, we combined for each of the selected countries the graphs of net selftranscendence scores from ESS and from PSS to allow for a discussion of directions of effects between value change in public opinion and in government.

\section{Data}

\section{ESS analysis}

Our aim was to verify if the public's value change may be associated with similar change in governments' value emphases, and to see chronologically in which direction these changes have occurred. For this particular aim, we focused our analysis on those EU countries with the most significant changes to the net selftranscendence score, both between the ESS1 and ESS5 and between two consecutive ESS rounds. The countries with the largest changes in these measures can be seen in Table 1 and Table 2 respectively. 
Table 1: Largest changes in net self-transcendence between ESS1 and ESS5

\begin{tabular}{cccc}
\hline \multicolumn{2}{c}{ Positive } & \multicolumn{2}{c}{ Negative } \\
\hline Spain & 0.55 & Czech Republic & -0.73 \\
Sweden & 0.34 & Ireland & -0.26 \\
Norway & 0.15 & Ukraine & -0.24 \\
\hline
\end{tabular}

Table 2: Largest changes in net self-transcendence between consecutive ESS rounds

\begin{tabular}{cccccc}
\hline & \multicolumn{1}{c}{ Positive } & \multicolumn{4}{c}{ Negative } \\
\hline Sweden & 0.27 & ESS5 & Czech Republic & -0.45 & ESS2 \\
Greece & 0.26 & ESS5 & Portugal & -0.35 & ESS2 \\
Portugal & 0.26 & ESS3 & Ireland & -0.33 & ESS5 \\
& & & Greece & -0.32 & ESS4 \\
\hline
\end{tabular}

As a result, the Czech Republic, Spain, Portugal, Sweden, Ireland, and Greece were selected for further study. Figures 2a-f show the evolution of selftranscendence and self-enhancement for these countries over time, mirroring each other.

Figures 2a-f: Public opinion self-transcendence and self-enhancement
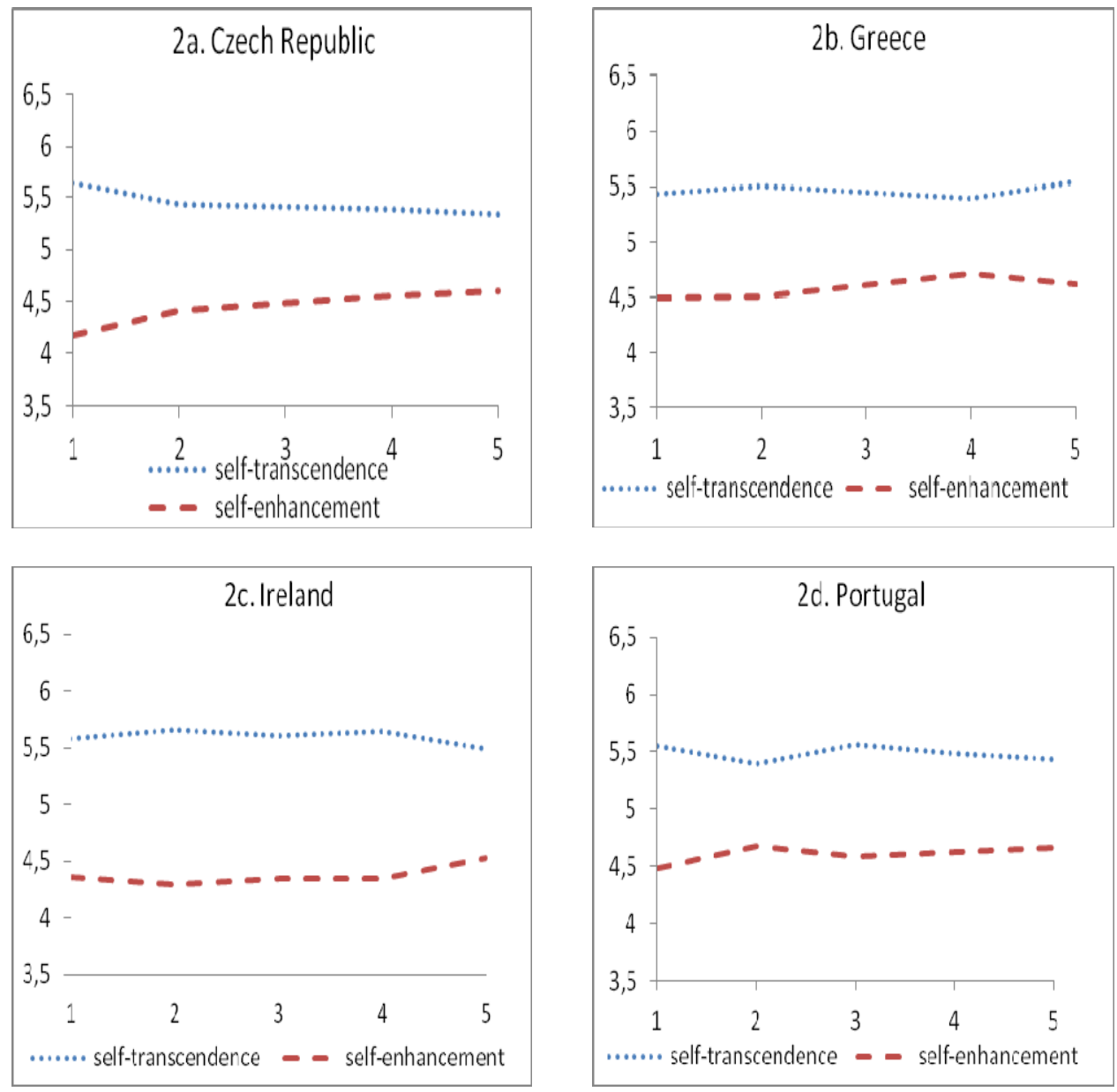

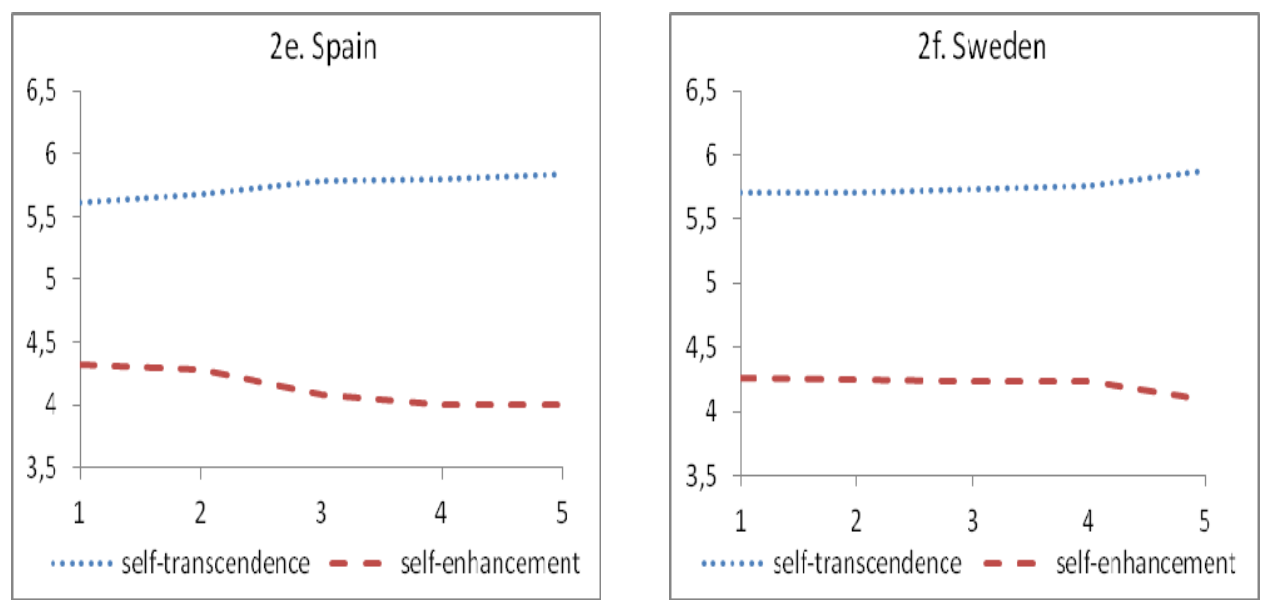

In Figure 3, the unpredictable evolution of the public opinion net selftranscendence score in all six countries is illustrated. For instance, Sweden has increased its score from a level that was already at the top. Spain started from a medium position and moved to the top of the list. Conversely, the Czech Republic started at the top only to end up with the lowest score of all six at the time of ESS5.

Figure 3: Public opinion net self-transcendence score for selected countries

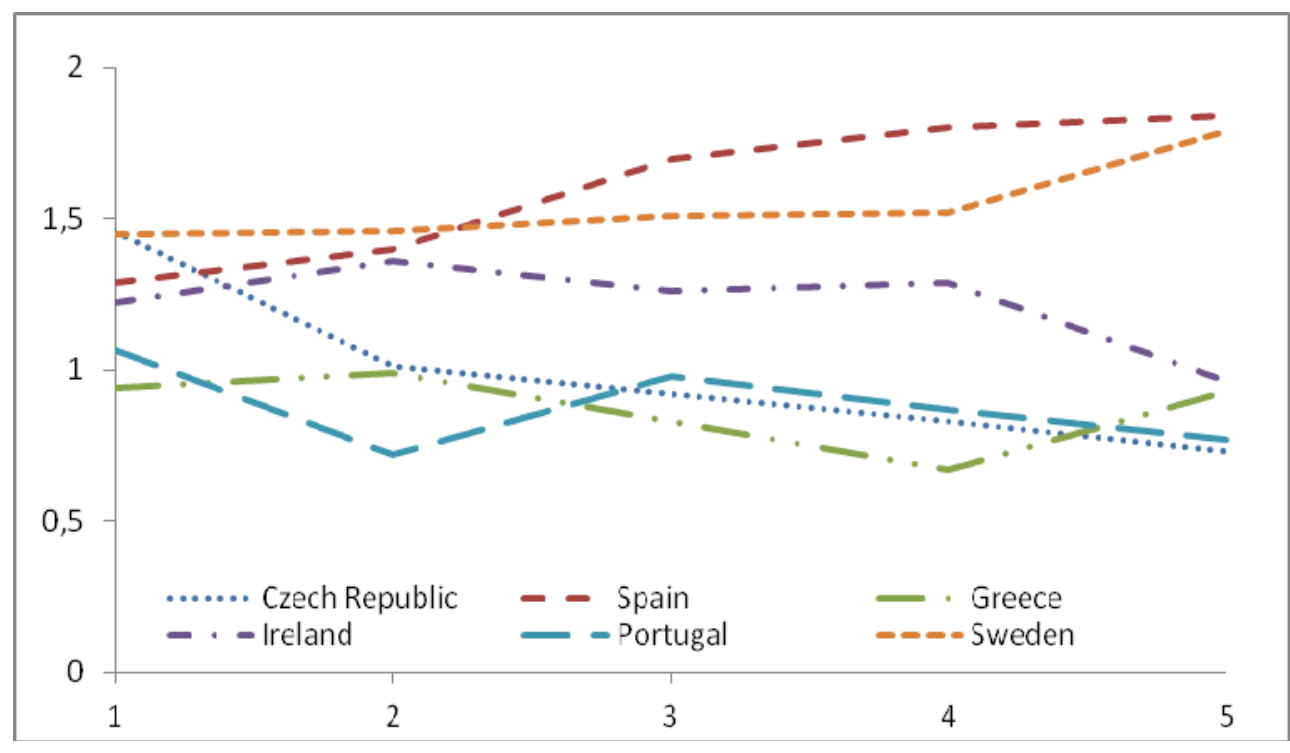

\section{The political scientist survey (PSS)}

The expert survey was carried out using the web service freeonlinesurveys.com which allowed the respondents to fill it in anonymously at their own leisure. Emails were sent to 8-16 political scientists in each country with a link to the survey and a two week period to respond. After nine days they were all approached again with a reminder by email. The average response rate was $41 \%$ between the six countries, with an average of 4 respondents each and 22 respondents in total. With the exception of the Czech Republic and Portugal, all respondents followed the instructions and filled in the survey for all their respective governments.

The inter-judge reliability, or the degree of agreement between the different respondents for each government, was calculated using Cronbach's alpha. The range of values calculated was 0.61-0.92, except for the lower cases of the Persson government in Sweden (0.47), the Barroso and Santana Lopes governments in Portugal (0.52 and 0.57, respectively) and all governments in 
Greece. It was found that the unreliability for the Greek case was caused mainly by one respondent. Once this data set was removed, all governments except for Karamanlis had acceptable Cronbach's alpha values of more than 0.6. The Karamanlis government, which remained at an astonishingly low 0.09 , is therefore treated with caution, as discussed under results.

\section{Results and discussion}

To investigate feedback loops between the value-priorities expressed through governmental policies and those expressed in public opinion, graphs were plotted showing net self-transcendence both for public opinion and governments. A high net self-transcendence score shows a tendency towards self-transcendence values whereas a low score shows a tendency towards self-enhancement values. The public opinion's net self-transcendence score is tracked on the primary vertical axis to the left and the governments' net self-transcendence score on the secondary vertical axis to the right (Figures 4, 5, 7, 8, 9 and 10).

As our primary interest is to explore whether changes to the value priorities reflected in a government's policies are associated with later changes to values of the public, we focus on the extent to which the graphs show that a change to the governments' scores precedes changes to that of the public's values, and we discuss each of the six countries based on the graphs with ESS and PSS data. To further our analysis, we also complement our results with election outcomes and opinion polls as well as data from the ESS on the political preferences of the respondents.

\section{Spain}

Figure 4: Net self-transcendence for Spain

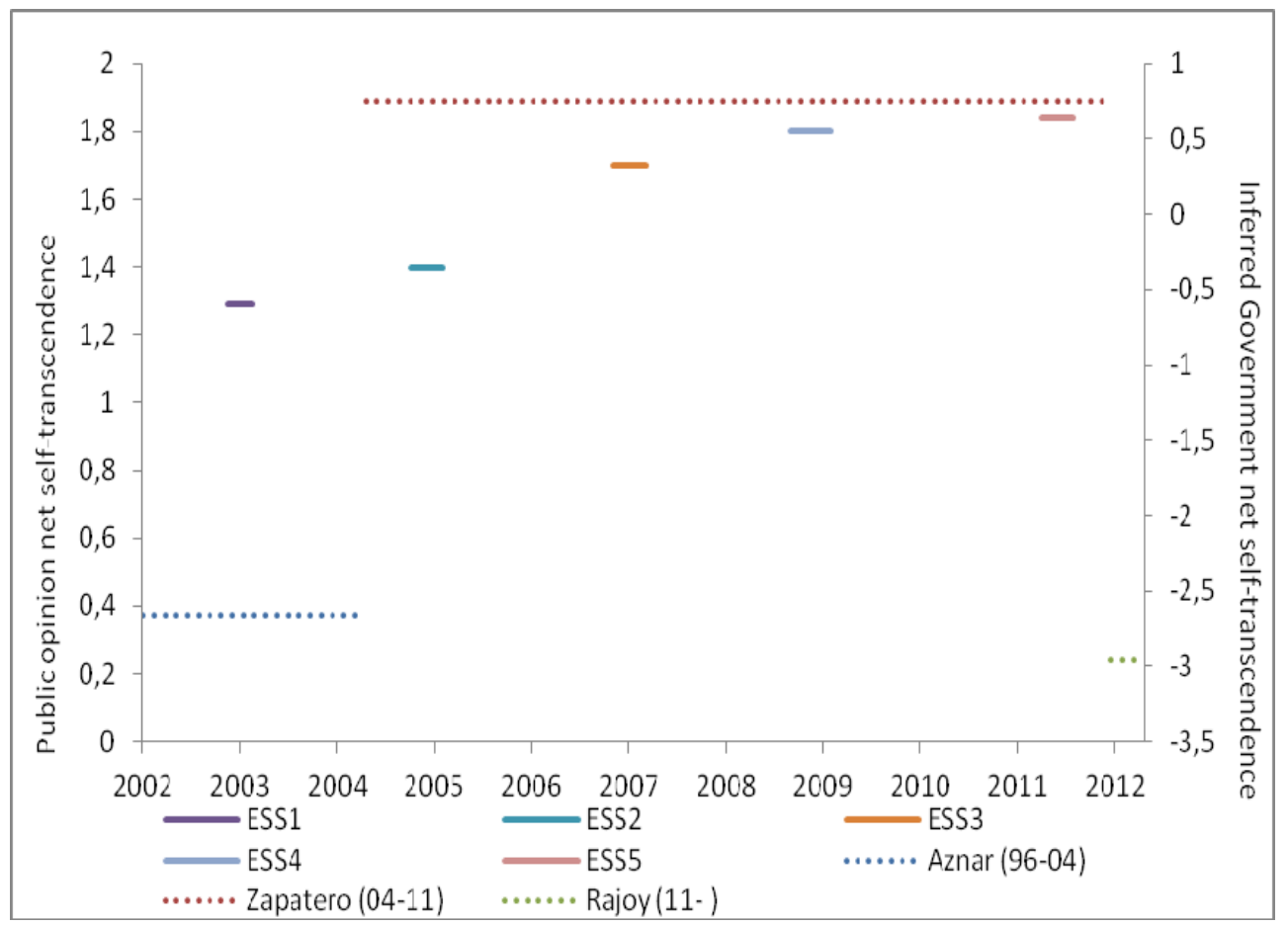

Spain has experienced the highest increase in the ESS net self-transcendence score. It appeared gradually and continuously between ESS1 and ESS5. The three Spanish governments in office 2002-2011 also show the clearest differences in their value priorities: The conservative Popular Party (PP) governments under José María Aznar (1996-2004) and Mariano Rajoy (2011-) both receive a net selftranscendence score about three points lower than the socialist PSOE government 
led by José Luis Rodríguez Zapatero (2004-2011). There is large consensus amongst PSS respondents in this assessment, with Cronbach's alpha of around 0.9 for all three governments. As the Zapatero government entered office between ESS1 and ESS2 and stayed in office until after ESS5, it means the interesting juncture to study is the change of government from Aznar to Zapatero, which resulted from the March 2004 general elections.

The run-up to the elections shows that Zapatero became prime minister by accident. The PP consistently led the opinion polls ahead of the 14 March elections (Libertad Digital, 2004). This changed with the 11 March 2004 Madrid train bombings, which left 191 dead and 1,800 injured. The government quickly blamed the Basque terrorist organisation ETA, despite evidence to the contrary. The government was seen to have tried to manipulate facts and the PP was consequently defeated (Gordon, 2004).

As mentioned above, the Zapatero government is seen to have been very clearly focused on self-transcendent political goals. The ESS data suggest that this may have triggered a policy feedback loop confirmed by his re-election in 2008.

Why, then, did the feedback loop stop at the general elections in 2011, after which the PP returned to government with a majority in parliament? We believe this may be explained by the economic crisis in which Spain has been engulfed since 2008 . With the recession, unemployment has soared. In none of the worst crisis-ridden euro-zone countries - Greece, Ireland, Italy, Portugal and Spain - have incumbents been re-elected after 2009. In other words, just like the exogenous event of the Madrid bombings may have triggered a policy feedback loop that took the Spanish public opinion's net self-transcendence score on an upward trend, another exogenous event - the economic crisis - may have put a halt to it.

Thus, the Spanish case suggests that, in the absence of large external shocks, governments may influence the value-priorities of the mass public rather than the other way round.

\section{Ireland}

Figure 5: Net self-transcendence for Ireland

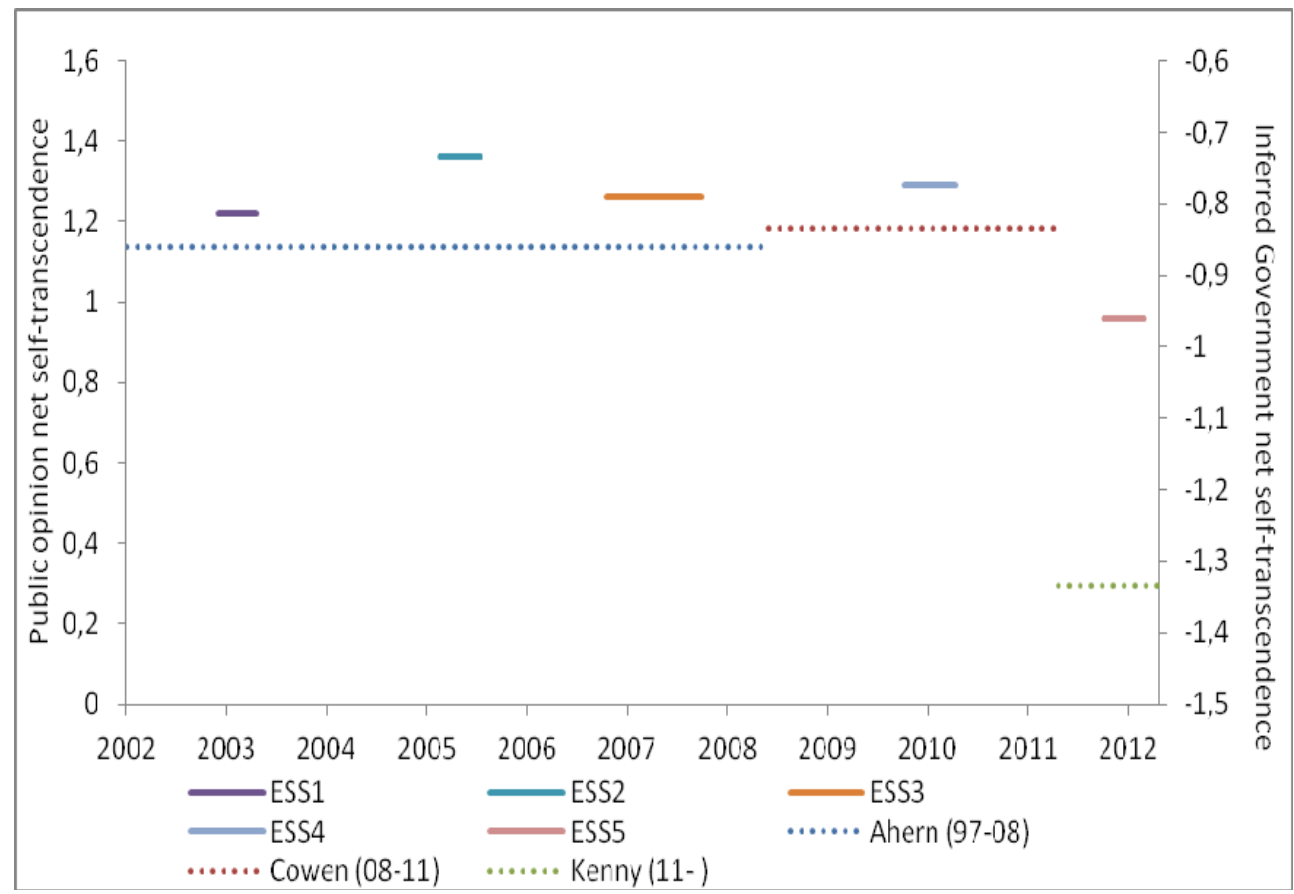


The Irish public opinion net self-transcendence score remains remarkably stable over most of the time period with relatively small oscillations up and down during the tenures of Bertie Ahern and Brian Cowen (both Fianna Fáil, centre-right). This is matched by a stable score for the same two governments in office until 2011. This picture changes dramatically with the last ESS round (2011-2012) and the change of government after the 2011 elections won by Enda Kenny's Fine Gael party (to the right of Fianna Fáil). Irish public opinion as well as the government turned massively towards self-enhancement. Judging from Figure 5 , both causal directions between public opinion and government value priorities are possible: ESS4 was recorded 11 September 2009-12 March 2010, the elections took place on 25 February 2011, and ESS5 was recorded 20 September 2011-31 January 2012. The drop in the public opinion net self-transcendence score between ESS4 and ESS5 could thus have occurred before or after the February 2011 elections. In any case, the fact that public opinion in ESS5 mirrors the Kenny government value priorities, indicate possible policy feedback.

To compare the two potential causal directions between changes to value priorities of government and those of public opinion, we look at opinion polls on voting intentions between ESS4 and ESS5 (Figure 6).

Figure 6: Irish opinion polls from ESS4 to 2011 election

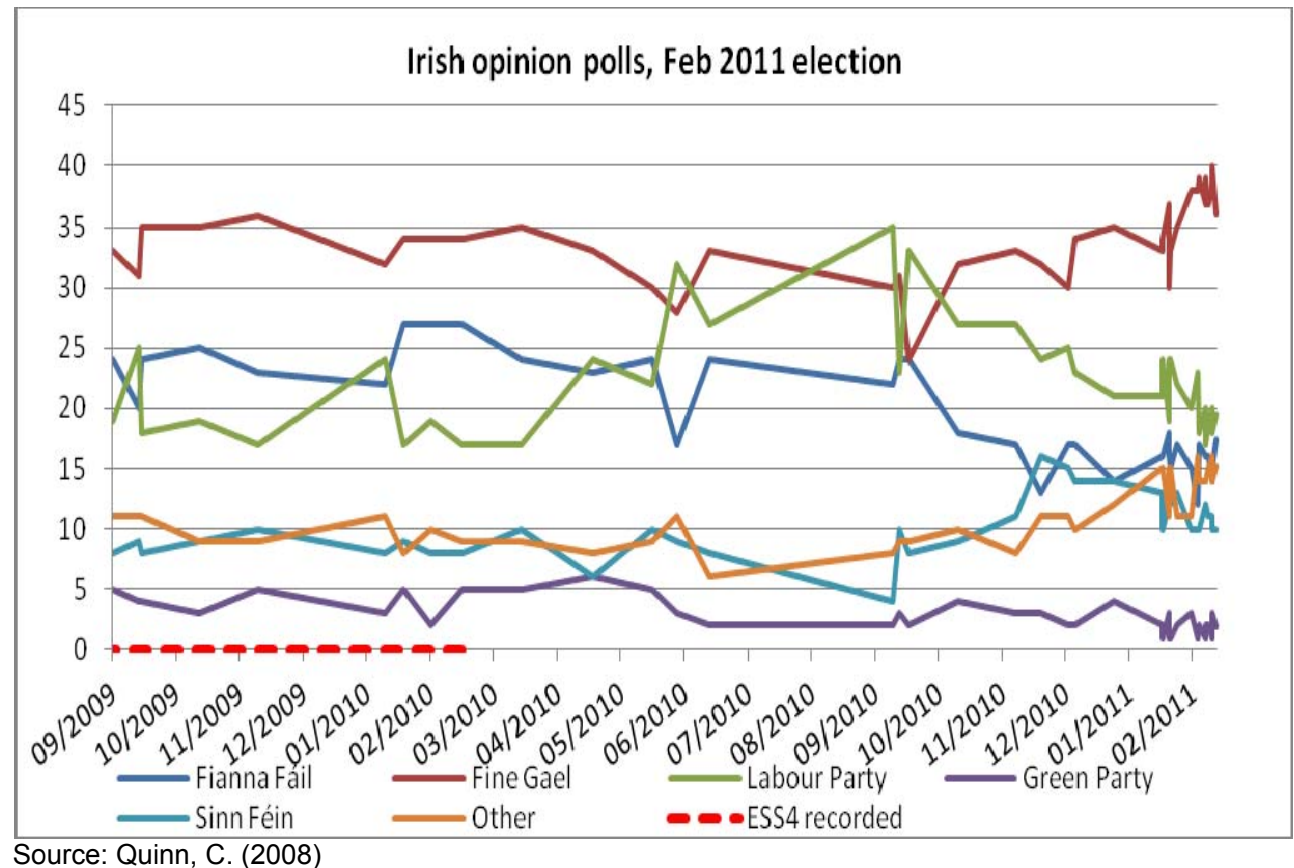

The polls show that Kenny's Fine Gael for most of the time period, including at the time ESS4 was recorded, had a score that was at a level similar to their election result in February 2011. It also had a consistent political line. If there was any feedback between value priorities of government and those of public opinion, it is more likely that the value change in public opinion occurred after the elections, which would be in line with our hypothesis. The victory of Fine Gael may be explained by the general pattern since 2009 that incumbents lose elections in crisis-ridden euro-zone countries. 


\section{Greece}

Figure 7: Net self-transcendence for Greece

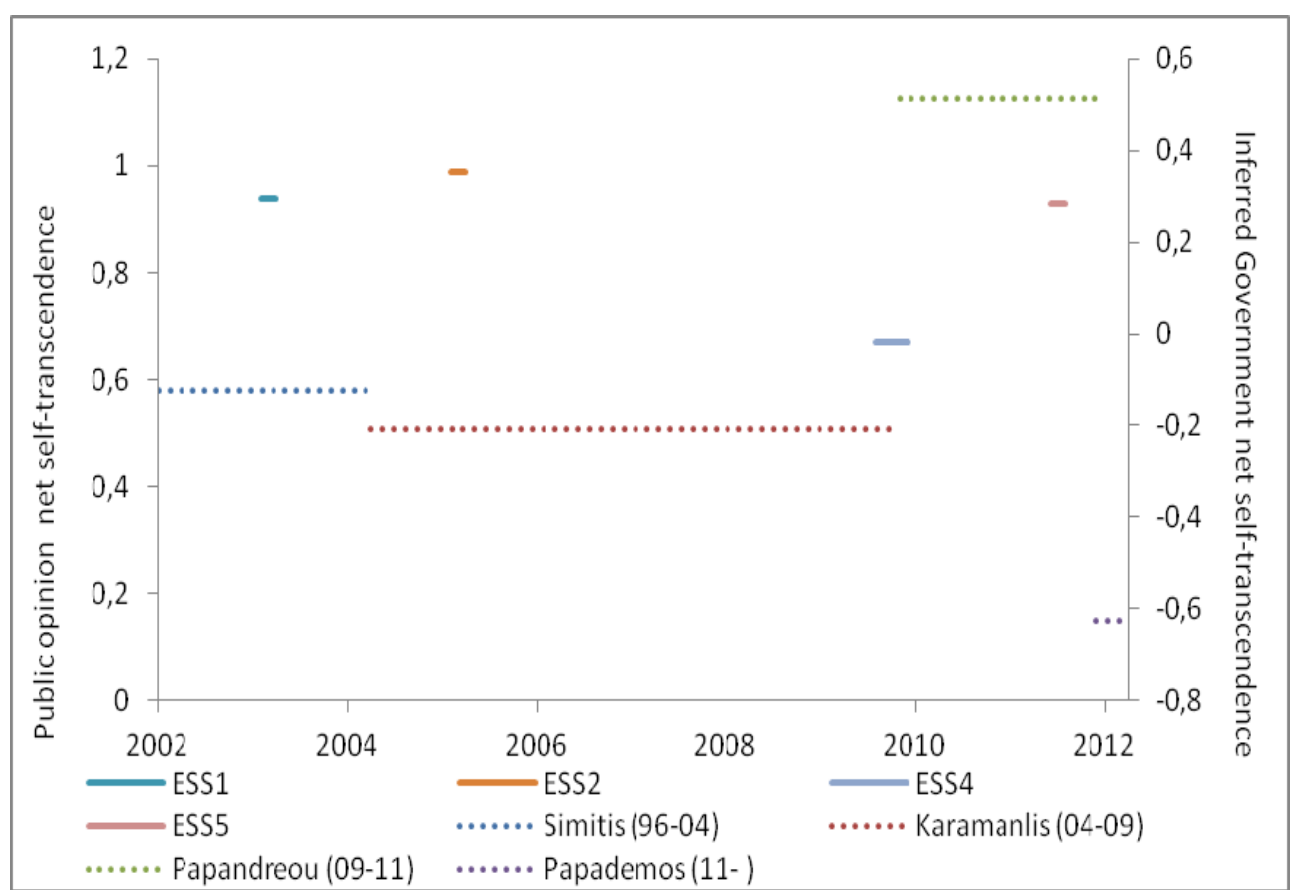

In Greece, the public opinion net self-transcendence score experienced a dip between ESS2 and ESS4 (Greece did not take part in ESS3) followed by an astonishing increase between ESS4 and ESS5. The government scores are stable until George Papandreou's PASOK (socialist) government 2009-2011, when it increases significantly and then drops even more with the care-taking government of Lucas Papademos. Note that the Kostas Karamanlis score needs to be interpreted with caution: The participants in the PSS differ widely in their assessment of his government.

We focus our attention on the most abrupt and significant change to the public opinion net self-transcendence score, between ESS4 and ESS5. ESS4 took place 15 July-20 November 2009. This was after PASOK had won the European elections in June 2009, confirmed by the general election on 4 October 2009 after which Karamanlis was replaced by Papandreou. Thus the public opinion net selftranscendence score at the time of the 2009 elections was rather contrary to the value priorities of Papandreou. Probably as a result of the deep economic crisis, the incumbent lost.

The subsequent rise of the public opinion net self-transcendence score under Papandreou provides some evidence favourable to our hypothesis that the government may influence public opinion more than the other way round. 


\section{Portugal}

Figure 8: Net self-transcendence for Portugal

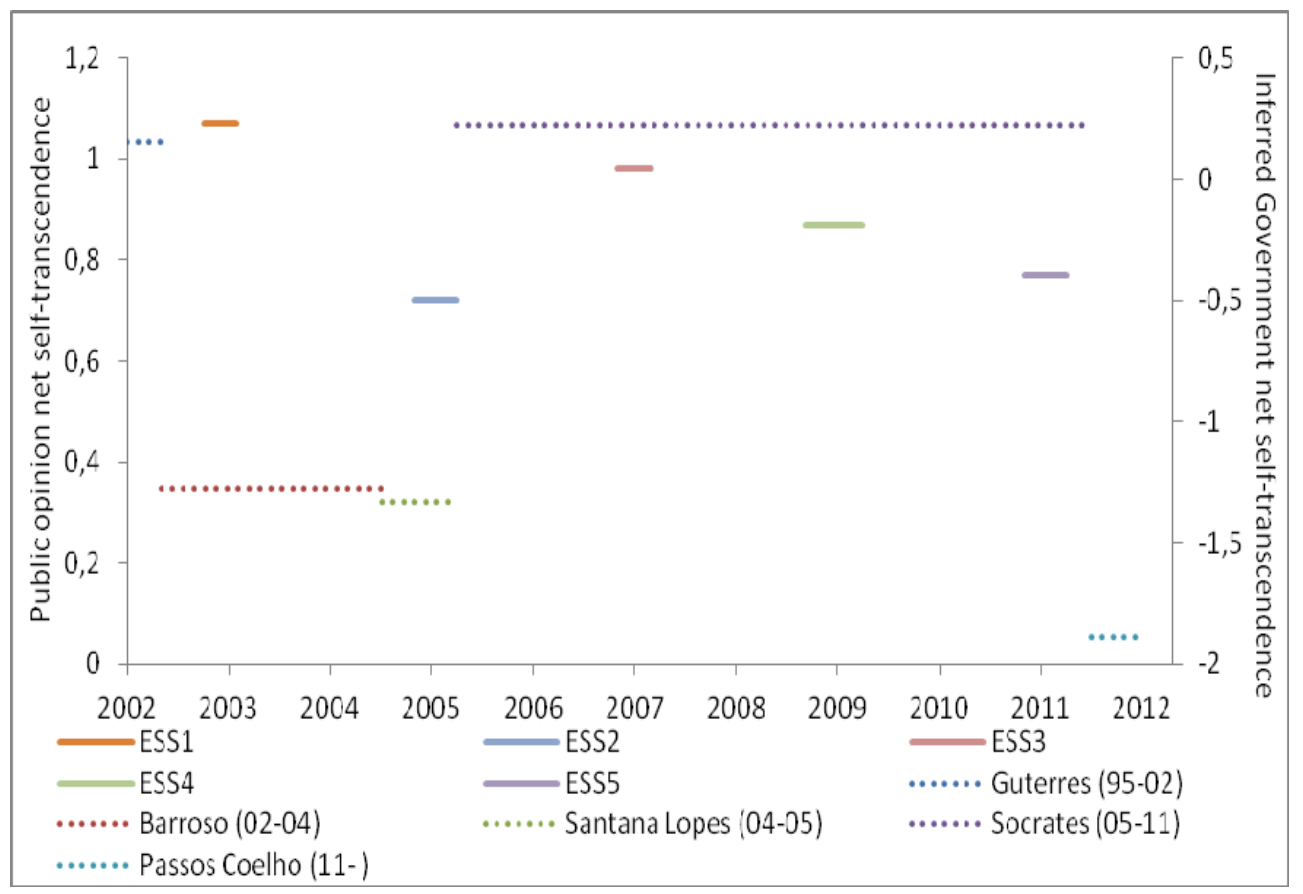

Portugal experienced a dramatic downward shift in public opinion's net selftranscendence score between ESS1 and ESS2. It then bounced back up by ESS3, although it remained below the ESS1 level. The dip corresponds to the Jose Manuel Barroso government 2002-2004 (Social Democratic Party, centre-right), followed by Pedro Santana Lopes 2004-2005 (also Social Democratic Party) after Barroso had been appointed president of the European Commission. Santana Lopes was defeated in the general elections of 20 February 2005 and was replaced by José Sócrates of the Socialist Party. The bounce between ESS2 and ESS3 corresponds to the first two years of the Sócrates government.

Portugal was the first country in the euro-zone to introduce fiscal austerity measures, under the Barroso government, after it had broken the EU Stability and Growth Pact ceilings on public deficits. This policy was not reversed by Santana Lopes. It is hardly surprising, then, that both governments appear largely selfenhancement oriented in the PSS (although there was significant disagreement amongst our respondents for both these governments, with Cronbach's alpha being 0.52 and 0.57 respectively). The Sócrates government from 2005 received a far higher net self-transcendence score.

As in the case of Greece, the coincidence of elections and ESS rounds makes it straightforward to test our hypothesis for the Santana Lopes/Sócrates shift. ESS2 was carried out from 15 October 2004 until 17 March 2005. In other words, about four of the survey's five months of interviews took place in the run-up to the elections. The ESS2 results show that the Portuguese public opinion had turned strongly towards self-enhancement during the Barroso and Santana Lopes tenures. Sócrates' victory seems more the result of a "sanction vote" against Santana Lopes, who carried the stigma of being a substitute for Barroso, had not held any national electoral office and presided over an economic slowdown and increased unemployment.

The subsequent jump in the public opinion net self-transcendence score between ESS2 and ESS3, during Sócrates' first two years in office, is in line with our hypothesis. It leaves unexplained the slight, but gradual, decrease in the public opinion's net self-transcendence score between ESS3 and ESS5, while Sócrates 
was still in office. This decrease was, however, far smaller than the changes between the three first ESS rounds. Sócrates' subsequent defeat at anticipated 2011 elections and replacement by Pedro Passos Coelho (whose government has a strong self-enhancement orientation) could give credence to the opposite to our hypothesis, in other words that a shift in public opinion's value priorities helped trigger the election of Passos Coelho. But this change of government could equally be put down to the general pattern of losing incumbents we also see in other crisisridden euro-zone countries.

Of the three changes of political parties in government in the period studied, the two first (Antonió Guterres/Barroso and Santana Lopes/Sócrates) could be interpreted in line with a causal effect of public policy on public opinion and the last one in line with the opposite effect.

\section{Czech Republic}

Figure 9: Net self-transcendence for the Czech Republic

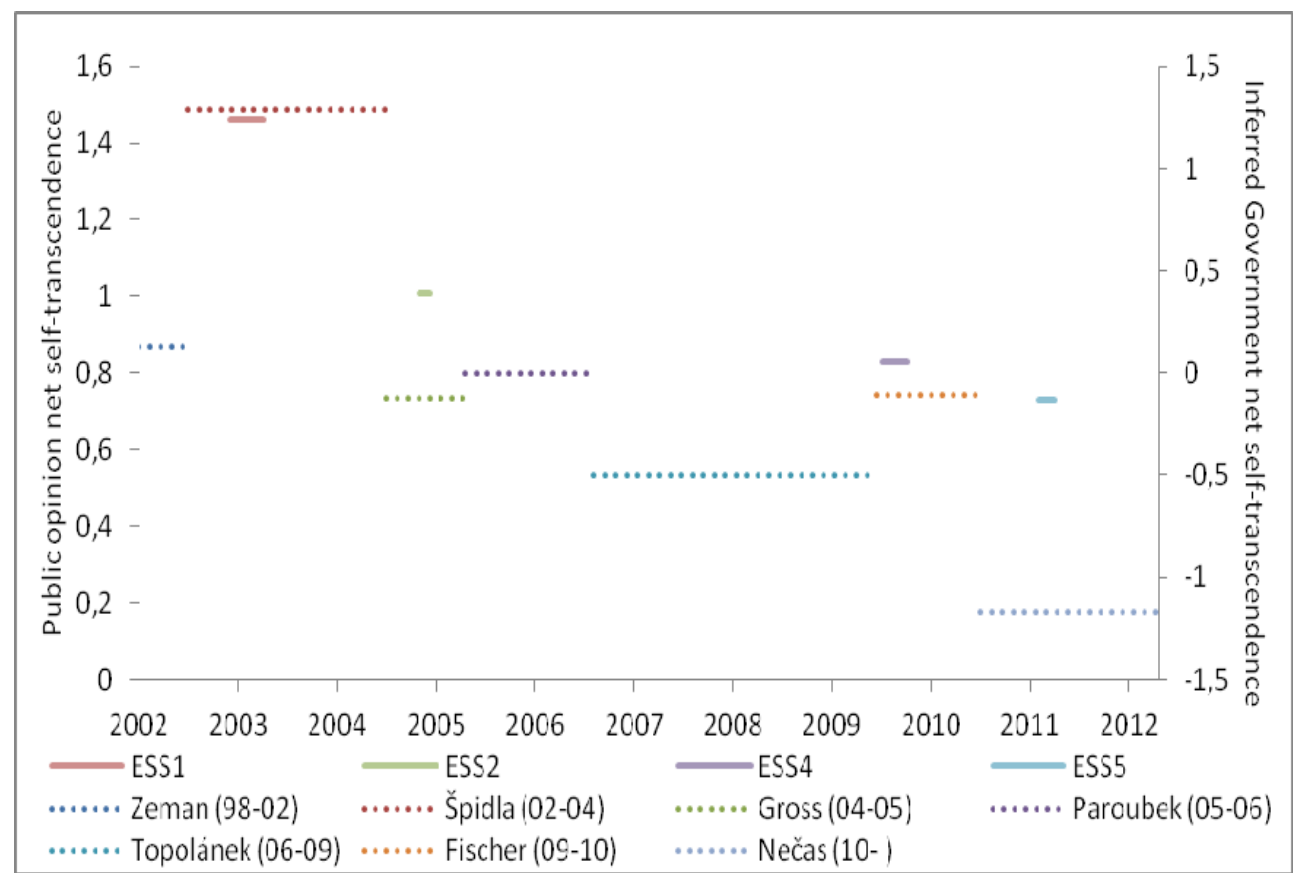

The Czech Republic has experienced a steady decline of the public opinion's net self-transcendence score. This started with the single biggest change between the scores of two subsequent ESS rounds: Between ESS1 (24 November 2002-9 March 2003) and ESS2 (1 October 2004-13 December 2004), it declined by almost 0.5 points. Between the two ESS rounds, no general elections were held but Stanislav Gross succeeded Vladimír Špidla as prime minister in August 2004. They were both from the same political party (ČSSD, social-democrats), but the Gross government received a much lower inferred net self-transcendence score than the Špidla government.

The trigger of the change of government was the European elections in June 2004 (Czech Statistical Office, 2004). The ČSSD lost votes both to the centre-right ODS party and to the communist party (KSČM), and ended up in fifth place. It should be noted that the rate of participation was very low (28.32\%). Špidla stepped down and was replaced by his deputy prime minister Gross, who was seen as a youthful, charismatic figure to reinvigorate the ČSSD. However, his premiership was quickly tainted by cronyism and corruption claims (The Economist, 2005), in contrast to the dull but honest reputation of Špidla. Gross was forced to resign in April 2005. 
It is difficult to find indicators that would support our hypothesis, given the large change of the public opinion's score but short period of time between Gross' entry into office in August 2004 and the ESS2 interviews (October-December 2004). It is easier to find indicators to test the opposite hypothesis: That shifts in value priorities of public opinion drove the changes to value priorities of government. An indicator would be if the rejection of the ČSSD were confirmed by a general move in ESS2 to the political right, as the political right is associated with selfenhancement in the Czech Republic. ESS data show that this was not the case between ESS1 and ESS2.

It is thus possible that other factors, such as the controversies around Gross and the cynicism about politics that he inspired, contributed to the change in the public opinion value-priorities between ESS1 and ESS2. It is also clear that prior to Gross' government, there was already a potential for cynicism building up, as the Špidla government had proven to be a fractious coalition and the prime minister was unable to carry out many of his pledges.

To sum up, there is no clear evidence for either causal relationship between shifts in the value priorities of governments and those of the public opinion for this country.

During the rest of the time period, there was a slower but steady decline in the public opinion's net self-transcendence score, accompanied by governments whose score remained relatively low and stable until 2010, when Petr Nečas took over as prime minister. Its net self-transcendence score is significantly lower than the preceding ones. However, with no clear trend breaks, neither in the ESS data nor in the government scores, we avoid comparing hypothetical causalities for the developments after the Gross government.

\section{Sweden}

Figure 10: Net self-transcendence for Sweden

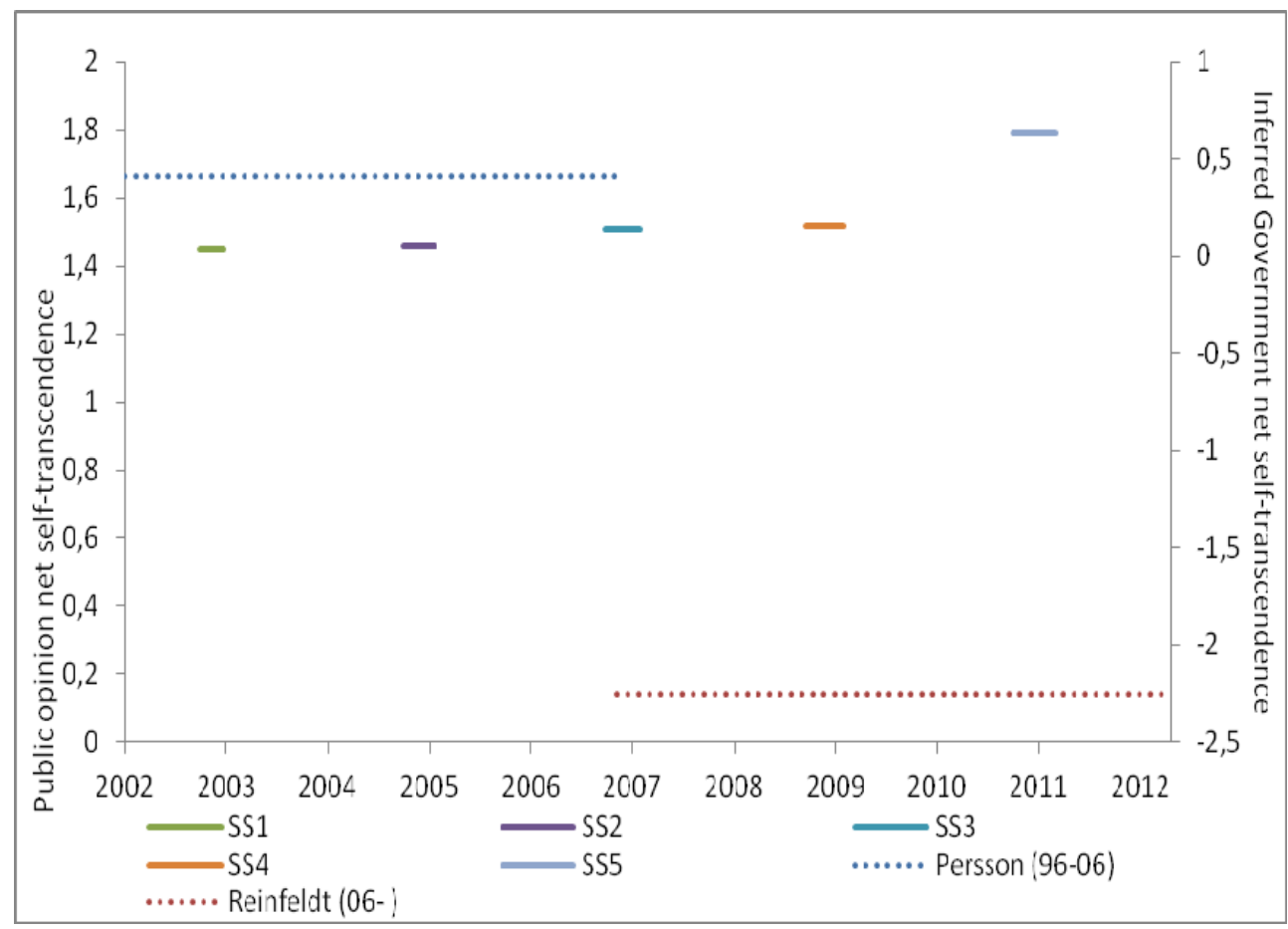

Sweden is one of the countries with the highest public opinion net selftranscendence score throughout all ESS rounds. The score was stable until a significant increase appeared between ESS4 and ESS5. The only change of prime minister occurred in 2006, when the social-democrat government led by Göran 
Persson was defeated in the general elections by a centre-right coalition led by Fredrik Reinfeldt of the conservative party (Moderaterna). The PSS in Sweden only comprised two respondents. Cronbach's alpha is satisfactory for Reinfeldt $(0.73)$ but not for Persson (0.47), which means its score should be interpreted with caution. However, the large difference between the two governments' score (more than 2.5 points) instills confidence that the Reinfeldt government's net selftranscendence score is lower than that of its predecessor.

If there were any causal links between shifts in value priorities of public opinion and those of the government, a shift in public opinion should have occurred either between ESS2 and ESS3 (which was conducted from 21 September 2006 to 3 February 2007, immediately after the September 2006 elections) or between ESS3 and ESS4 (which was conducted after two years of the Reinfeldt government). Neither of them occurred. Other factors have been at play to increase the public opinion net self-transcendence score between ESS4 (2008-9) and ESS5 (20102011). Thus, in the Swedish case we do not find any clear evidence for a public policy-public opinion effect.

\section{Conclusions}

In three (Spain, Greece and Ireland) of the six EU Member States with the highest changes to public opinion net self-transcendence scores, findings are in line with the idea that governments' value priorities as expressed through public policy may predict - in the same direction - self-transcendence values of public opinion. The impact of such possible influence on re-election is, however, secondary to exogenous shocks, such as economic downturns or trust-breaking revelations of government misdoings. The combination of these factors - exogenous shocks and government's influence on public opinion - can produce contrasted trends, as exemplified by Greece and Ireland: An acute economic crisis left incumbents defeated in elections in 2009 and 2011 respectively; the new Greek government had more self-transcendent political goals compared to its predecessor, whereas the new Irish government had more self-enhancement oriented political goals. In the ESS round carried out after these elections, public opinion had moved in the direction indicated by the respective government changes.

In two cases (Czech Republic and Portugal) there is support for feedback loops between value priorities expressed in government policies and public opinion, but the data do not enable us to disentangle the direction of effects in the feedback loop (Czech Republic), or they point to effects in both directions (Portugal). The Czech case is, however, interesting by the fact that it is the country with the highest increase in the purchasing power standard per inhabitant and the only one with a fall in the unemployment rate throughout the period of all the six countries studied, yet with the biggest decrease in the public opinion net self-transcendence score. It confirms the insight from the contrasting cases of Ireland and Greece that economic trends do not determine the direction of change in public opinion value priorities.

In the last case (Sweden), we have not found support for any influence between government and public opinion's value priorities.

This paper is intended merely as a preliminary attempt to investigate the existence and possible directions of effects between value priorities of the government and those of public opinion, the confirmation of which would require, inter alia:

Inclusion of the other ESS countries (in particular to compare with countries with small variations to public opinion net self-transcendence scores - specifically, Slovenia, Netherlands, Great Britain, Denmark, Switzerland and Belgium)

- Inclusion of feedback loops between governments and public opinion on the value dimension Openness to Change vs. Conservation 
- Better validation of the PSS design and a higher number of respondents in each country

- More objective measures of government's value priorities

- Quantitative analysis with control factors such as economic growth or unemployment

- Inclusion of ESS6 data (2012-2013)

- Systematic consideration of socio-economic variables

With these caveats, we draw the cautious conclusion that there are indeed possible feedback loops between the value priorities of governments and of public opinion, and that the values expressed by governments may influence value priorities of the public more than the other way round. This can have far-reaching implications for political strategies to solve Bigger-Than-Self problems such as child poverty or climate change. Appeals to economic growth as an end in itself may undermine voters' willingness to finance welfare services to fight, for instance, child poverty. Arguing for investments in renewable energy primarily as a competitive necessity to prevent trading partners from "catching" future jobs could reduce voters' support for strong climate change policies in general.

If our conclusions are confirmed by others, it will also give more confidence to politicians who want to focus on Bigger-Than-Self problems. The politicians' influence is not limited to the direct effect of policies adopted under their tenure; their rhetoric and their policies can make citizens more supportive of action to tackle such problems - even beyond the next election.

\section{References}

Altemeyer, Bob (1998) 'The other "authoritarian personality"' in Mark P. Zanna (ed.) Advances in experimental social psychology. San Diego, CA: Academic, pp. 47-92.

Amara, Roy C. (1972) 'Toward a Framework for National Goals and Policy Research', Policy Sciences 3(1): 59-69.

Bardi, Anat and Lilach Sagiv (2003) 'The EU and Israel: Comparison of cultures and implications' in Klaus Boehnke (ed.) Israel and Europe: A complex relationship. Wiesbaden: Deutscher Universitäts-Verlag, pp. 13-26.

Bardi, Anat and Robin Goodwin, (2011) 'The dual route to value change: Individual processes and cultural moderators', Journal of Cross-Cultural Psychology 42(2): 271-287.

Bardi, Anat, Kathryn E. Buchanan, Robin Goodwin, Letitia Slabu and Mark Robinson (2014) 'Value stability and change during self-chosen life transitions: Self-selection versus socialization effects', Journal of Personality and Social Psychology 106(1): 131-147.

Barnea, Marina F. and Schwartz, Shalom H. (1998) 'Values and Voting', Political Psychology 19(1): 17-39.

Brewer, Paul R. and Kimberly Gross (2005) 'Values, Framing, and Citizens' Thoughts about Policy Issues: Effects on Content and Quantity', Political Psychology 26(6): 929-948.

Burstein, Paul (2003) 'The Impact of Public Opinion on Public Policy: A Review and an Agenda', Political Studies Quarterly 56(1): 29-40.

Caprara, Gian Vittorio, Shalom Schwartz, Cristina Capanna, Michele Vecchione and Claudio Barbaranelli (2006) 'Personality and Politics: Values, Traits and Political Choice', Political Psychology 27(1): 1-28. 
Cochran, Charles and Eloise F. Malone (1995) Public Policy. New York: McGrawHill.

Converse, Philip (1964). 'The Nature of Belief Systems in Mass Publics', in David Apter (ed.) Ideology and Discontent. New York: Free Press, pp. 206-261.

Crompton, Tom (2010). Common Cause: The Case for Working with our Cultural Values. WWF-UK. URL (consulted April 2014): http://assets.wwf.org.uk/downloads/common_cause_report.pdf

Czech Statistical Office (2004). URL (consulted April 2014): http://www.volby.cz/pls/ep2004/ep11?xjazyk=EN

Dahl, Robert A. (1989). Democracy and its Critics. New Haven, CT: Yale University Press.

Davidov, Eldad, Peter Schmidt and Shalom H. Schwartz (2008) 'Bringing Values Back In. The Adequacy of the European Social Survey to Measure Values in 20 Countries', Public Opinion Quarterly 72(3): 420-445.

De Groot, Judith I. M. and Linda Steg (2008) 'Value Orientations to Explain Beliefs Related to Environmental Significant Behavior: How to Measure Egoistic, Altruistic, and Biospheric Value Orientations', Environment and Behavior 40(3): 330-354.

Dror, Yehezkel (1973) Public Policy Reexamined. London: Leonard Hill Books.

Duit, Andreas (2011) 'Patterns of Environmental Collective Action: Some CrossNational Findings', Political Studies 59 (4): 900-920.

Easton, David (1953) The Political System. New York: Knopf.

The Economist (2005, 3-9 March) Gross misdemeanours. URL (consulted April 2014): http://www.economist.com/node/3723535

European Social Survey Round 5 Data (2010) Data file edition 2.0. Norwegian Social Science Data Services, Norway - Data Archive and distributor of ESS data.

European Social Survey Cumulative File, ESS 1-4 (2011) Data file edition 1.0. Norwegian Social Science Data Services, Norway - Data Archive and distributor of ESS data.

Feldman, Stanley (1988) 'Structure and Consistency in Public Opinion: the Role of Core Beliefs and Values', American Journal of Political Science 32(2): 416-440.

Fiorina, Morris P. (1981). Retrospective Voting in American National Elections. New Haven, CT: Yale University Press.

Gilbert, Daniel T., Susan T. Fiske and Gardner Lindzey (1998) The handbook of social psychology. Oxford: Oxford University Press.

Glynn, Carroll J., Susan Herbst, Garrett J. O'Keefe and Robert Y. Shapiro (1999) Public Opinion. Boulder, CO: Westview Press.

Gordon, Philip H. (2004) Madrid Bombings and U.S. Policy. Testimony to the Senate Committee on Foreign Relations. URL (consulted April 2014): http://www.brookings.edu/research/testimony/2004/03/31europe-gordon

Hayek, Friedrich A. (1960) The Constitution of Liberty. Chicago, IL: University of Chicago Press.

Hjern, Benny (1987) 'Policy Analysis: An Implementation Approach', Paper presented at the Annual Meeting of the American Political Science Association, 3-6 September 1987, Chicago.

Hodge, lan and Sandra McNally (2000) 'Wetland restoration, collective action and the role of water management institutions', Ecological Economics 35(1): 107-118. 
Holmes, Tim, Elena Blackmore, Richard Hawkins and Tom Wakeford (2011) The Common Cause Handbook. Public Interest Research Centre. URL (consulted April 2014): http://valuesandframes.org

Hofstede, Geert (1980) Culture's consequences: International differences in workrelated values. Beverly Hills, CA: Sage.

Hurwitz, Jon and Mark Peffley (1987) 'How are foreign policy attitudes structured? A hierarchical model', American Political Science Review 81(4): 1099-1120.

Jacobs, Lawrence R. and Robert Y. Shapiro (2000) Politicians Don't Pander: Political Manipulation and the Loss of Democratic Responsiveness. Chicago, IL: University of Chicago Press.

Jacoby, William (2006) 'Value Choice and American Public Opinion', American Journal of Political Science 50(3): 706-723.

Jenkins-Smith, Hank and Paul Sabatier (1993) 'Methodological Appendix: Measuring Longitudinal Change in Elite Beliefs Using Content Analysis of Public Documents', in Paul Sabatier and Hank Jenkins-Smith (eds) Policy Change and Learning: An Advocacy Coalition Approach. Boulder, CO: Westview Press, pp. 237-276.

Kingdon, John W. (1995) Agendas, alternatives and public policies (2nd edition). New York: HarperCollins.

Libertad Digital (2004) Encuestas y sondeos. URL (consulted April 2014): http://www.libertaddigital.com/suplementos/elecciones2004/encuestas.html

MacKuen, Michael B., Robert S. Erikson and James A. Stimson (1992). 'Peasants or Bankers? The American Electorate and the US Economy', American Political Science Review 86(3): 597-611.

Ostrom, Elinor (2000) 'Crowding out citizenship', Scandinavian Political Studies 23(1): 3-16.

Page, Benjamin I. and Robert Y. Shapiro (1983) 'Effects of public opinion on policy', American Political Science Review 77(1): 175-190.

Pierson, Paul (1993) 'When Effect Becomes Cause: Policy Feedback and Political Change', World Politics 45(4): 595-628.

Premfors, Rune (1989) Policyanalys: kunskap, praktik och etik $i$ offentlig verksamhet. Lund: Studentlitteratur.

Quinn, Ciaran (2008) Na Pobalbhreitheanna is deireanaí. URL (consulted July 2013): http://www.guthanphobail.net/pobalbhreitheanna.htm

Rasinski, Kenneth R. (1987) 'What's fair is fair-or is it? Public values and conflicting views about justice', Journal of Personality and Social Psychology 53(1): 201-211.

Rein, Martin and Donald Schön (1993) 'Reframing Policy Discourse', in Frank Fischer and John Forester (eds) The Argumentative Turn in Policy Analysis and Planning. Durham, NC: Duke University Press, pp. 145-166.

Rohan, Meg J. and Mark P. Zanna (1996) 'Value Transmissions in Families', in Clive Seligman, James M. Olson and Mark P. Zanna (eds) The Psychology of Values: The Ontario Symposium, Vol. 8. New Jersey: Lawrence Erlbaum Associates Publishers, pp. 253-76.

Rohan, Meg J. and Mark P. Zanna (1998) 'The "products of socialization": A discussion of self-regulatory strategies and value systems', in Joel Cooper and John M. Darley (eds) Attribution and social interaction: The legacy of Edward E. Jones. Washington DC: American Psychological Association, pp. 279-292. 
Rokeach, Milton (1973) The Nature of Human Values. New York, NY: The Free Press.

Sabatier, Paul A. and Hank C. Jenkins-Smith (1999) 'The Advocacy Coalition Framework: An Assessment', in Paul A. Sabatier (ed), Theories of the Policy Process. Boulder, CO: Westview Press, pp. 117-166.

Sagiv, Lilach and Shalom H. Schwartz (1995) 'Value priorities and readiness for out-group social contact', Journal of Personality and Social Psychology 69(3): 437448.

Schattschneider, Elmer E. (1935) Politics, Pressures and the Tariff: A Study of Free Private Enterprise in Pressure Politics, as Shown in the 1929-1930 Revision of the Tariff. New York: Prentice-Hall.

Schultz P. Wesley, Valdiney V. Gouveia, Linda D. Cameron, Geetika Tankha, Peter Schmuck and Marek Franěk (2005) 'Values and their Relationship to Environmental Concern and Conservation Behavior', Journal of Cross-Cultural Psychology 36(4): 457-475.

Schwartz, Shalom H. (1992) 'Universals in the content and structure of values: Theory and empirical tests in 20 countries', in Mark P. Zanna (ed) Advances in experimental social psychology (Vol. 25). New York: Academic Press, pp. 1-65.

Schwartz, Shalom H. (1994) 'Beyond Individualism-Collectivism: New cultural dimensions of values', in Uichol Kim, Harry C. Triandis, Cigdem Kagitcibasi, SangChin Choi and Gene Yoon (eds) Individualism and collectivism: Theory, method, and applications. London: Sage, pp. 85-119.

Schwartz, Shalom H. (2006) Basic Human Values: An Overview. Jerusalem: The Hebrew University of Jerusalem.

Schwartz, Shalom H. (2007) 'A Theory of Cultural Value Orientations: Explication and Applications', in Yilmaz R. Esmer and Thorleif Petterson (eds) Measuring and Mapping Cultures: 25 Years of Comparative Value Surveys. Leiden: Brill, pp. 3378.

Schwartz, Shalom H. (2011) 'Values: Individual and cultural', in Fons J. R. van de Vijver, Athanasios Chasiotis and Seger M. Breugelmans (eds) Fundamental questions in cross-cultural psychology. Cambridge, MA: Cambridge University Press, pp. 463-493.

Schwartz, Shalom H. and Anat Bardi (1997) 'Influences of adaptation to communist rule on value priorities in Eastern Europe', Political Psychology 18(2): 385-410.

Skocpol, Theda (1992) Protecting Soldiers and Mothers: The Political Origins of Social Policy in the United States. Cambridge, MA: Harvard University Press.

Soroka, Stuart and Christopher Wlezien (2004) 'Opinion Representation and Policy Feedback: Canada in Comparative Perspective', Canadian Journal of Political Science 37(3): 531-559.

Soroka, Stuart and Christopher Wlezien (2010) Degrees of Democracy. Cambridge: Cambridge University Press.

Soss, Joe (1999) 'Lessons of Welfare: Policy Design, Political Learning, and Political Action', American Political Science Review 93(2): 363-380.

Soss, Joe and Sanford F. Schram (2007) 'A Public Transformed? Welfare Reform as Policy Feedback', American Political Science Review 101(1): 111-127.

Stern, Paul C. and Thomas Dietz (1994) 'The value basis of environmental concern', Journal of Social Issues 50(3): 65-84.

Stern, Paul C., Thomas Dietz, Linda Kalof and Gregory A. Guagnano (1995) 'Values, Beliefs, and Proenvironmental Action: Attitude Formation Toward 
Emergent Attitude Objects', Journal of Applied Social Psychology 25(18): 16111636.

Stewart, Jenny (2009) Public Policy Values. Basingstoke: Palgrave Macmillan.

Stimson, James A., Michael B. Mackuen and Robert S. Eriksson (1995) 'Dynamic Representation', American Political Science Review 89(3): 543-565.

Svallfors, Stefan (2010) 'Policy feedback, generational replacement, and attitudes to state intervention: Eastern and Western Germany, 1990-2006', European Political Science Review 2(1): 119-135.

Tetlock, Philip E., Randall S. Peterson and Jennifer S. Lerner (1996) 'Revising the value pluralism model: Incorporating social content and context postulates', in Clive Seligman, James M. Olson and Mark P. Zanna (eds) The Ontario Symposium of Values, Vol. 8. New Jersey: Lawrence Erlbaum Associates Inc., pp. 25-47.

Thacher, David and Martin Rein (2004) 'Managing Value Conflict in Public Policy', Governance: An International Journal of Policy, Administration, and Institutions 17(4): 457-486.

Wallner, Jennifer (2008) 'Legitimacy and Public Policy: Seeing Beyond Effectiveness, Efficiency, and Performance', The Policy Studies Journal 36(3): 421443.

Wlezien, Christopher (1995) 'The Public as Thermostat: Dynamics of Preferences for Spending', American Journal of Political Science 39(4) 981-1000.

Wlezien, Christopher (1996) 'Dynamics of Representation: The Case of US Spending on Defence', British Journal of Political Science 26(1): 81-103.

Wlezien, Christopher (2004) 'Patterns of Representation: Dynamics of Public Preferences and Policy', Journal of Politics 66(1): 1-24.

Zaller, John R. (1992) The nature and origins of mass opinion. New York: Cambridge University Press. 


\section{Appendix}

Items of the political scientists' survey (PSS) and correspondence with Schwartz value types

\begin{tabular}{|c|c|c|c|}
\hline & Government priority & Corresponding PVQ items in ESS & $\begin{array}{c}\text { Inferred } \\
\text { corresponding } \\
\text { Schwartz value } \\
\text { type }\end{array}$ \\
\hline 1 & Economic growth & $\begin{array}{l}\text { It is important to her/him to be rich. She/he wants to have a } \\
\text { lot of money and expensive things. }\end{array}$ & Achievement \\
\hline 2 & $\begin{array}{l}\text { Publicly funded services (e.g. } \\
\text { health, pensions, education and } \\
\text { transport funded through taxes } \\
\text { and compulsory social security } \\
\text { contributions) }\end{array}$ & $\begin{array}{c}\text { She/he thinks it is important that every person in the world } \\
\text { should be treated equally. She/he believes everyone should } \\
\text { have equal opportunities in life. }\end{array}$ & Universalism \\
\hline 3 & $\begin{array}{l}\text { Making domestic companies } \\
\text { more competitive against foreign } \\
\text { ones }\end{array}$ & $\begin{array}{l}\text { Being very successful is important to her/him. She/he hopes } \\
\text { people will recognise her/his achievements. }\end{array}$ & Achievement \\
\hline 4 & Respect for authority & $\begin{array}{l}\text { It is important to her/him to get respect from others. She/he } \\
\text { wants people to do what she/he says. } \\
\text { It is important to her/him to be loyal to her/his friends. }\end{array}$ & Power \\
\hline 5 & Fight corruption & $\begin{array}{c}\text { She/he wants to devote herself/himself to people close to } \\
\text { her/him. }\end{array}$ & Benevolence \\
\hline 6 & $\begin{array}{l}\text { Liberalisation of regulated } \\
\text { sectors }\end{array}$ & $\begin{array}{l}\text { Being very successful is important to her/him. She/he hopes } \\
\text { people will recognise her/his achievements. }\end{array}$ & Achievement \\
\hline 7 & $\begin{array}{l}\text { Redistribution (from richer to } \\
\text { poorer households) }\end{array}$ & $\begin{array}{l}\text { It's very important to her/him to help the people around } \\
\text { her/him. She/he wants to care for their well-being. }\end{array}$ & Benevolence \\
\hline 8 & $\begin{array}{l}\text { Tolerance (for different lifestyles, } \\
\text { appearances and beliefs) }\end{array}$ & $\begin{array}{l}\text { It is important to her/him to listen to people who are different } \\
\text { from her/him. Even when she/he disagrees with them, } \\
\text { she/he still wants to understand them. }\end{array}$ & Universalism \\
\hline 9 & $\begin{array}{l}\text { Reducing the top marginal } \\
\text { income tax rate }\end{array}$ & $\begin{array}{l}\text { It's important to her/him to show her/his abilities. She/he } \\
\text { wants people to admire what she/he does. }\end{array}$ & Achievement \\
\hline 10 & $\begin{array}{l}\text { Helping other countries in need } \\
\text { and showing solidarity with them }\end{array}$ & $\begin{array}{c}\text { She/he thinks it is important that every person in the world } \\
\text { should be treated equally. She/he believes everyone should } \\
\text { have equal opportunities in life. }\end{array}$ & Universalism \\
\hline 11 & Prestige of the country & $\begin{array}{l}\text { It is important to her/him to get respect from others. She/he } \\
\text { wants people to do what she/he says. }\end{array}$ & Power \\
\hline 12 & Protection of the environment & $\begin{array}{l}\text { She/he strongly believes that people should care for nature. } \\
\text { Looking after the environment is important to her/him. }\end{array}$ & Universalism \\
\hline
\end{tabular}

\section{Processing of responses}

Responses were coded numerically as follows:

\begin{tabular}{cc}
\hline Option & Value \\
\hline Contrary to goals: & -2 \\
Indifferent: & 0 \\
Goal unless public opposition: & 1 \\
One of priority goals: & 2 \\
The most important goal: & 3 \\
\hline
\end{tabular}

More options with positive than negative values were given as we expected more answers with positive values and hence it was reasonable to allow for more nuances to express these. This was confirmed by the distribution of answers. This is also why the only option with a negative value was set at -2 to reflect the fact that the options with positive values ranged from 1 to 3 . 